\title{
PEMBIAYAAN MUDHARABAH DAN KAITANNYA DENGAN NON PERFORMING FINANCING(NPF) DAN BAGI HASIL
}

\author{
Sri Indah Nikensari* \\ Dian Sugiarti** $^{* *}$ \\ Tuty Sariwulan ${ }^{* * *}$
}

\begin{abstract}
ABSTRAC
Economic development in Indonesia require funding from many sources. One source of funding is from the Islamic banks in recent years experienced a very rapid expansion, both of the institution and the assets and the distribution of funds.

This study aims to look at the link between non-performing financing (NPF) (X1) and the profit sharing ratio (X2) to the amount of mudharabah financing $(Y)$ in Islamic banks and Islamic business units in Indonesia. But in the process of analysis, because of autocorrelation, then added the other explanatory variables are mudharabah financing at the previous period (X3).

The results showed a significant effect of the profit sharing ratio received by the bank (X2), then the mudharaba financing at the previous period (X3) to the mudharaba financing at current period $(Y)$, but the magnitude of the NPF last period had no significant effect to the amount of mudarabah financing at current period. The lack of effect of NPF to the meaninglessness of financing was indicated that the handling of non-performing loans (NPF) used rescheduling and reconditioning scheme and financing into qordhul hasan. Although partially NPF had no significant effect to the financing, but together these three explanatory variables have a significant impact on financing. The coefficient of determination indicates the amount of 0.991 , which means that 99\% more variation in the mudharaba financing can be explained by the three explanatory variables.
\end{abstract}

Keywords: Mudharabah Financing, non performance financing, qordhul hasan, profit sharing ratio 


\section{PENDAHULUAN}

Krisis moneter yang
pernah mengguncang Indonesia 1998 telah menyadarkan banyak pihak tentang pentingnya fundamental ekonomi yang kuat dan pemberdayaan ekonomi rakyat. Sektor moneter yang tidak ditopang oleh sektor riil yang kuat ditengarai menyimpan bom waktu yang menunggu momen untuk meruntuhkan capaian-capaian pembangunan ekonomi nasional. Kegagalan sektor moneter yang tidak didukung fundamental ekonomi kerakyatan telah terbukti meruntuhkan pertumbuhan ekonomi dunia, ketika dunia dilanda krisis ekonomi yang parah di tahun 2008, yang dimulai dari Amerika Serikat, yang dipicu oleh anjlognya bursa saham besar dunia karena kinerja keuangan perusahan-perusahaan di bursa melemah.

Fundamental ekonomi yang kuat, yang didukung oleh ekonomi rakyat, memerlukan dukungan pembiayaan yang kooperatif. Salah satu sumber pembiayaan yang

\footnotetext{
${ }^{*}$ Dosen Fakultas Ekonomi Universitas Negeri Jakarta

** Alumni Fakultas Ekonomi Universitas Negeri Jakarta

*** Dosen Fakultas Ekonomi Universitas Negeri Jakarta
}

kooperatif tersebut adalah bersumber dari perbankan syariah. Perbankan syariah menjadi salah satu alternatif sumber pembiayaan bagi kegiatan ekonomi masyarakat, dan saat ini sedang berkembang cukup pesat, karena beberapa kelebihan yang dimilikinya.

Pertumbuhan bank syariah itu sendiri di Indonesia menunjukkan perkembangan yang menggembirakan. Menurut data Bank Indonesia, saat ini terdapat 11 Bank Umum Syariah (BUS) yang beroperasi di Indonesia dengan nilai asset per Januari 2012 sebesar Rp 115,3 trilyun, atau tumbuh $46 \%$ dibandingkan pada Januari 2011 yang senilai Rp 78,2 trilyun. Sedangkan asset 24 Unit Usaha Syariah (UUS) per Januari 2012 adalah 28,6 trilyun, atau tumbuh 63\% dibandingkan Januari 2011 yang hanya berjumlah $\mathrm{Rp} 17,9$ trilyun. Selain itu asset 155 Bank Pembiayaan Rakyat Syariah per Januari sebesar Rp 3,61 trilyun, meningkat 30,1\% dibanding posisi Januari 2011 yaitu sebesar Rp 2,77 trilyun.

Perbankan syariah sebagai
bentuk implementasi konsep
ekonomi syariah mempunyai spirit
keberpihakan kepada sektor riil
terutama usaha menengah ke


bawah. Perbankan syariah yang tidak mengenal rezim bunga, namun menawarkan kerjasama yang saling menguntungkan antara pemilik modal (shahibul mal) dengan pengusaha (mudharib). Salah satu pembiayaan bagi kegiatan ekonomi masyarakat yang bersumber dari bank syariah adalah pembiayaan mudharabah. Beberapa kelebihan pembiayaan mudharabah bank syariah, sesuai fatwa DSN 07/DSNMUI/IV/2000 tentang Pembiayaan Mudharabah (Qiradh), antara lain menggunakan sistem bagi hasil bukan sistem bunga, di mana jangka waktu usaha, tatacara pengembalian dana, dan pembagian keuntungan ditentukan berdasarkan kesepakatan kedua belah pihak (LKS dengan pengusaha); pembiayaan mudharabah tidak ada jaminan (namun agar mudharib tidak melakukan penyimpangan, bank dapat meminta jaminan dari mudharib atau pihak ketiga); tidak ada ganti rugi, karena pada dasarnya akadnya bersifat amanah (yad al-amanah), kecuali akibat dari kesalahan disengaja, kelalaian, atau pelanggaran kesepakatan, dan masih banyak lagi kelebihan dari pembiayaan ini.

Namun dengan beberapa kelebihan yang dimilikinya, ternyata pertumbuhan pembiayaan mudharabah bank syariah di Indonesia masih kalah dibandingkan pertumbuhan pembiayaan murabahah (pembiayaan jual-beli) dan pembiayaan lainnya. Padahal pembiayaan mudharabah merupakan salah satu keunggulan bank syariah dibandingkan bank konvensional karena mengedepankan prinsip kemitraan dan keadilan.

Tabel di bawah ini menggambarkan komposisi pembiayaan yang diberikan oleh Perbankan Umum Syariah di Indonesia tahun 2008 sampai dengan 2011:

Tabel I.1 Komposisi Pembiayaa BUS dan UUS di Indonesia (Milyar Rp)

\begin{tabular}{|l|l|l|l|l|}
\hline Akad & $\mathbf{2 0 0 8}$ & $\mathbf{2 0 0 9}$ & $\mathbf{2 0 1 0}$ & $\mathbf{2 0 1 1}$ \\
\hline Mudharabah & 6.205 & 6.597 & 8.631 & 10.229 \\
\hline Musyarakah & 7.411 & 10.412 & 14.624 & 18.960 \\
\hline Murabahah & 22.486 & 26.321 & 37.508 & 56.365 \\
\hline Salam & 0 & 0 & 0 & 0 \\
\hline Istishna & 369 & 423 & 347 & 326 \\
\hline Ijarah & 765 & 1.305 & 2.341 & 3.839 \\
\hline
\end{tabular}




\begin{tabular}{|l|l|l|l|l|}
\hline Akad & $\mathbf{2 0 0 8}$ & $\mathbf{2 0 0 9}$ & $\mathbf{2 0 1 0}$ & $\mathbf{2 0 1 1}$ \\
\hline Qordh & 959 & 1.829 & 4.731 & 12.937 \\
\hline Lainnya & 0 & 0 & 0 & 0 \\
\hline Total & 38.195 & 46.886 & 68.181 & 102.655 \\
\hline
\end{tabular}

Sumber : BI, Statistik Perbankan Syariah, 2012

Tabel 1.1 di atas daya secara efisien dapat menunjukkan bahwa besarnya pembiayaan mudharabah lebih kecil dibandingkan besarnya pembiayaan murabahah. Porsi pembiayaan mudharabah terhadap total pembiayaan mengalami penurunan pada tahun 2008 sebesar $16,24 \%$ menurun di 2009 menjadi 14,07\%, tahun 2010 sebesar $12,66 \%$ dan tahun 2011 mencapai 9,96\%. Sementara dilihat dari pertumbuhannya, pembiayaan murabahah cukup signifikan dibandingkan dengan pembiayaan musyarakah dan mudharabah. Padahal jenis pembiayaan yang diharapkan untuk membantu meningkatkan kegiatan produksi masyarakat adalah jenis pembiayaan mudharabah dan musyarokah, bukan murabahah.

Banyak faktor yang mempengaruhi besarnya pembiayaan mudharabah, baik dari dalam perusahaan perbankan sendiri maupun dari luar perbankan. Faktor internal, misalnya efisiensi sumber daya yang ada pada bank syariah, pengendalian biaya dan posisi resiko. Penggunaan sumber memengaruhi tingkat pembiayaan yang disalurkan termasuk pembiayaan mudharabah. Sumber daya yang dihimpun perbankan syariah bersumber dari simpanan atau dana pihak ketiga, pinjaman serta modal sendiri (ekuitas). Hal ini sesuai dengan pendapat RoseKolari yang dikutip oleh Priatin dan Adnan (2005:36) bahwa sumbersumber dana yang bisa digunakan untuk pembiayaan adalah simpanan (giro, tabungan, deposito berjangka), pinjaman bank sentral (pinjaman likuiditas), pinjaman dari institusi keuangan internasional dan modal ekuitas (modal disetor, laba ditahan, cadangan).

Tingkat pengendalian biaya dan posisi resiko pun dapat mempengaruhi besarnya jumlah pembiayaan perbankan syariah, selain jumlah simpanan dan modal sendiri. Faktor ini dapat dilihat dari tingkat kredit bermasalah atau dalam bank konvensional disebut Non Performing Loan (NPL), sedangkan bank syariah menggunakan istilah Non Performing Financing (NPF). 
Menurut Djoko Retnadi dkk (2005:113), angka NPL yang tinggi bagi sebuah bank komersial merupakan salah satu indikator yang sering dipakai untuk memprediksi prospek kelangsungan hidup bank itu sendiri. Tingginya tingkat kredit bermasalah mempresentasikan tingginya resiko pembiayaan yang disalurkan oleh perbankan syariah.

Faktor eksternal yang mempengaruhi pembiayaan bank syariah misalnya dengan melihat kompetensi dari lembaga keuangan lainnya. Kompetensi ini dicerminkan dengan tingkat prosentase bagi hasil dan mark up keuntungan yang ada pada perbankan syariah. Nisbah bagi hasil (profit sharing ratio) mempunyai pengaruh dalam perhitungan bagi hasil pada suatu bank. Bank syariah semaksimal mungkin menetapkan tingkat bagi hasil sama dengan atau lebih besar dari suku bunga bank konvensional serta menerapkan kebijakan mark up keuntungan yang lebih rendah dibandingkan suku bunga kredit bank konvensional (Antonio, M Syafi'i. 2001).

\section{Perumusan Masalah}

Berdasarkan latar belakang di atas, maka masalah yang diteliti dapat dirumuskan sebagai berikut:

1. Apakah terdapat pengaruh antara non performing financing terhadap pembiayaan mudharabah pada Perbankan Syariah di Indonesia?

2. Apakah terdapat pengaruh antara bagi hasil terhadap pembiayaan mudharabah pada Perbankan Syariah di Indonesia?

3. Apakah terdapat pengaruh antara non performing financing dan tingkat bagi hasil terhadap pembiayaan mudharabah pada Perbankan Syariah di Indonesia?

\section{TINJAUAN PUSTAKA}

\section{Pembiayaan Mudharabah}

Financing atau pembiayaan adalah pendanaan yang dikeluarkan untuk mendukung investasi yang telah direncanakan, baik dilakukan sendiri maupun dijalankan oleh orang lain. Dalam arti sempit, pembiayaan dipakai untuk mendefinisikan pendanaan yang dilakukan oleh lembaga pembiayaan, seperti bank syariah kepada nasabah (Muhammad, 2002:304). Muhammad dalam buku lainnya (2004:183) mendefinisikan pembiayaan sebagai penyediaan dana dan atau tagihan berdasarkan akad mudharabah dan atau musyarakah dan atau pembiayaan lainnya berdasarkan prinsip bagi hasil. Mudharabah adalah perjanjian antara penanam 
dana dan pengelola dana untuk melakukan kegiatan usaha tertentu dengan pembagian keuntungan antara kedua belah pihak berdasarkan nisbah yang telah disepakati sebelumnya.

Berdasarkan pengertian di atas, mudharabah merupakan suatu bentuk equity financing, tetapi hubungan kontraknya bukan antara pemberi modal melainkan antara pihak penyedia dana dalam hal ini adalah bank dengan pihak pengelola dana yaitu nasabah sebagai pengusaha (entrepreneur). Pengelola dana dapat berupa perorangan ataupun perusahaan yang bertujuan melakukan perdagangan. Jika proyek selesai, pengusaha akan mengembalikan modal kepada bank berikut porsi keuntungan yang telah disetujui sebelumnya. Bila terjadi kerugian, maka seluruh kerugian dipikul oleh bank, sedangkan pengusaha kehilangan keuntungan atas kerja yang telah dilakukannya.

Ada dua tipe mudharabah, yaitu mutlaqah (tidak terikat) dan muqayyadah (terikat) (Nadratuzzaman, dkk, 2008: 119):

a. Mudharabah mutlaqah : pemilik dana memberikan keleluasaan penuh kepada pengelola untuk menggunakan dana tersebut dalam usaha yang dianggapnya baik dan menguntungkan. Pengelola bertanggungjawab untuk mengelola usaha sesuai dengan praktek kebiasaan usaha normal yang sehat.

b. Mudharabah muqayyadah : pemilik dana menentukan syarat dan pembatasan kepada pengelola dalam penggunaan dana tersebut dengan jenis usaha, tempat usaha, dan pihakpihak yang dibolehkan terlibat dalam usaha. Pengelola menggunakan dana tersebut dengan tujuan yang dinyatakan secara khusus, yaitu untuk menghasilkan keuntungan.

Masih

menurut

Nadratuzzaman dkk (2008: 119), pembiayaan mudharabah sebagai bentuk kerjasama antara dua atau lebih pihak dimana pemilik modal (shahibul maal) mempercayakan sejumlah modal kepada pengelola (mudharib) dengan suatu perjanjian pembagian keuntungan. Bentuk ini menegaskan kerjasama dengan kontribusi $100 \%$ modal dari shahibul maal dan keahlian dari mudharib. Transaksi jenis ini tidak mensyaratkan adanya wakil pemilik modal dalam manajemen proyek. Sebagai orang kepercayaan, pengelola harus bertindak hati-hati 
dan bertanggungjawab untuk setiap kerugian yang terjadi akibat kelalaian. Sedangkan sebagai wakil pemilik modal, pengelola diharapkan untuk dapat mengelola modal dengan cara tertentu untuk menciptakan laba optimal.

Ketentuan umum yang berlaku dalam akad mudharabah adalah (Nadratuzzaman, dkk, 2008:120-121):

a. Jumlah modal yang diserahkan kepada nasabah selaku pengelola modal, harus diserahkan tunai dapat berupa uang atau barang yang dinyatakan nilainya dalam satuan uang. Apabila modal diserahkan secara bertahap, harus jelas tahapannya dan disepakati bersama.

b. Hasil dan pengelolaan modal pembiayaan mudharabah dapat diperhitungkan dengan dua cara:

(1) Perhitungan dari pendapatan proyek

(2) Perhitungan dari keuntungan proyek

c. Hasil usaha dibagi sesuai dengan persetujuan dalam akad, pada setiap bulan atau waktu yang disepakati. Bank selaku pemilik modal menanggung seluruh kerugian kecuali akibat kelalaian dan penyimpangan pihak nasabah, seperti penyelewengan, kecurangan dan penyalahgunaan dana.

d. Bank berhak melakukan pengawasan terhadap pekerjaan namun tidak berhak mencampuri urusan pekerjaan/usaha nasabah. Jika nasabah cidera janji dengan sengaja misalnya tidak mau membayar kewajiban atau menunda pembayaran kewajiban, dapat dikenakan sanksi administrasi.

Pendapat senada dikemukakan oleh Muhammad Syafi'i Antonio (2002) mengenai pembiayaan mudharabah, bahwa Al-mudharabah adalah akad kerjasama usaha antara dua pihak dimana pihak pertama (shahibul maal) menyediakan seluruh (100\%) modal, sedangkan pihak lainnya menjadi pengelola. Keuntungan usaha secara mudharabah dibagi menurut kesepakatan yang dituangkan dalam kontrak, sedangkan apabila rugi ditanggung oleh pemilik modal selama kerugian itu bukan akibat kelalaian si pengelola. Seandainya kerugian itu diakibatkan karena kecurangan atau kelalaian si pengelola, si pengelola harus bertanggung jawab atas kerugian tersebut. Manfaat adanya 
pembiayaan mudharabah ini, diantaranya adalah :

a. Ketika keuntungan usaha nasabah meningkat, maka bank juga menikmati peningkatan bagi hasil yang didapat sesuai nisbah yang telah disepakati.

b. Bank tidak pernah mengalami negative spread karena bank tidak berkewajiban membayar bagi hasil kepada nasabah pendanaan secara tetap, tetapi disesuaikan dengan hasil usaha bank.

c. Nasabah tidak akan merasa terbebani karena pengembalian pokok pembiayaan disesuaikan dengan arus kas usaha nasabah.

d. Bank akan lebih berhati-hati dalam menyalurkan dananya karena keuntungan yang konkret yang akan dibagikan.

Berdasarkan definisi di atas, secara umum dikatakan bahwa pembiayaan mudharabah adalah pembiayaan yang diberikan bank syariah untuk membiayai kerjasama usaha dimana bank menyediakan $100 \%$ modal untuk dikelola oleh pihak lain yang memiliki keahlian. Pembagian keuntungan didasarkan pada nisbah yang telah disepakati bersama oleh pihak bank dengan nasabah.

\section{Non Performing Financing (NPF)}

Bank Syariah dalam
operasional sehari-hari juga
dihadapkan pada berbagai risiko
yang berkaitan dengan fungsinya
sebagai perantara keuangan
(intermediary), sehingga bank syariah sebagai suatu entitas bisnis juga mempunyai risiko atas kegiatan usahanya (Suhardjono, 2003: 73). Risiko adalah penyimpangan hasil aktual dari hasil yang diharapkan (risk is the dispersion of actual from expected results) atau risiko adalah probabilitas sesuatu hasil yang berbeda dari yang diharapkan (risk is the probability of any aoutcome different from the one expected).

Salah satu risiko yang dihadapi oleh perbankan adalah adanya default nasabah atau ketidakmampuan nasabah untuk memenuhi perjanjian dengan bank syariah. Default nasabah ini akan mengakibatkan adanya pembiayaan bermasalah atau non performing financing. Suhardjono (2003) menyebutkan bahwa, pengertian kredit bermasalah adalah suatu keadaan dimana nasabah sudah tidak sanggup membayar sebagian atau seluruh kewajibannya kepada bank seperti yang telah 
diperjanjikan dalam perjanjian kredit.

Lukman Dendawijaya (2001) memberikan pengertian tentang Non Performing Financing (NPF) atau Non Performing Loan (NPL) yaitu kredit yang kategori kolektabilitasnya masuk dalam kriteria kurang lancar, diragukan dan macet. Pendapat Lukman Dendawijaya didukung dalam Pernyataan Standar Akuntansi Keuangan (PSAK) No.31 tentang akuntansi perbankan (revisi 2002) butir 24 yang menyebutkan bahwa kredit non performing pada umumnya merupakan kredit yang pembayaran angsuran pokok dan atau bunganya telah lewat sembilan puluh hari atau lebih setelah jatuh tempo atau kredit yang pembayarannya secara tepat waktu sangat diragukan. Kredit non performing terdiri atas kredit yang digolongkan sebagai kredit kurang lancar, diragukan dan macet (Slamet Wiyono, 2005).

Kredit bermasalah juga didefinisikan sebagai pinjaman dana yang mengalami kesulitan pelunasan akibat adanya faktor kesengajaan dan atau karena faktor eksternal diluar kemampuan kendali debitur. Tingkat Non Performing Financing (NPF) pada suatu bank dapat dilihat dari kualitas aktiva produktif, yaitu keadaan pembayaran angsuran pokok dan bunga kredit atau bagi hasil pembiayaan oleh nasabah serta tingkat kemungkinan diterimanya kembali yang ditanamkan dalam surat-surat berharga atau sering disebut juga dengan istilah kolektabilitas.

Adapun kategori kolektabilitas kredit bermasalah terdiri dari tiga bagian, yakni :

a. Kurang lancar (substandard). Kredit kurang lancar adalah kredit yang pengembalian pokok pinjaman dan pembayaran bunganya telah mengalami penundaan selama 3 (tiga) bulan dari waktu yang diperjanjikan.

b. Diragukan (doubtful). Kredit diragukan adalah kredit yang pengembalian pokok pinjaman dan pembayaran bunganya telah mengalami penundaan selama 6 (enam) bulan atau dua kali lipat dari jadwal yang telah diperjanjikan.

c. Macet (loss), kredit macet adalah kredit yang pengembalian pokok pinjaman dan pembayaran bunganya telah mengalami penundaan lebih dari satu tahun sejak jatuh tempo menurut jadwal yang telah diperjanjikan. 
Berikut ini adalah tabel berdasarkan kemampuan bayar kategori pembiayaan bermasalah nasabah di Bank Syariah:

Tabel 2.1 Kriteria Kualitas Pembiayaan

Berdasarkan Kemampuan Bayar Nasabah

\begin{tabular}{|c|c|c|c|}
\hline \multirow{2}{*}{ Jenis } & \multicolumn{3}{|c|}{ Kategori } \\
\hline & Kurang lancar & Diragukan & Macet \\
\hline $\begin{array}{l}\text { Murabahah } \\
\text { Istishna', } \\
\text { Ijarah, Qard }\end{array}$ & $\begin{array}{l}\text { Tunggakan lebih } \\
\text { dari } 90 \text { hari s.d } \\
180 \text { hari }\end{array}$ & $\begin{array}{l}\text { Tunggakan lebih } \\
\text { dari } 180 \text { hari s.d } \\
270 \text { hari }\end{array}$ & $\begin{array}{l}\text { Tunggakan } \\
\text { lebih dari } 270 \\
\text { hari }\end{array}$ \\
\hline Salam & $\begin{array}{l}\text { Telah jatuh tempo } \\
\text { s.d } 60 \text { hari }\end{array}$ & Telah jatuh tempo & $\begin{array}{l}\text { Lebih dari } 90 \\
\text { hari s.d } 90 \text { hari }\end{array}$ \\
\hline $\begin{array}{l}\text { Mudharabah, } \\
\text { Musyarakah }\end{array}$ & $\begin{array}{l}\text { Tunggakan s.d } 90 \\
\text { hari; realisasi bagi } \\
\text { hasil di atas } \\
\text { s.d } 90 \% \\
\text { proyeksi } \\
\text { pendapatan }\end{array}$ & $\begin{array}{l}\text { Tunggakan lebih } \\
\text { dari } 90 \text { s.d } 180 \text { hari; } \\
\text { realisasi bagi hasil } \\
\text { kurang dari } 30 \%\end{array}$ & $\begin{array}{l}\text { Tunggakan } \\
\text { lebih } 180 \text { hari; } \\
\text { realisasi bagi } \\
\text { hasil kurang } \\
\text { dari } 30 \% \text { dari } \\
\text { proyeksi } \\
\text { pendapatan } \\
\text { lebih } \\
\text { dari } 3 \text { periode } \\
\text { pembayaran. }\end{array}$ \\
\hline
\end{tabular}

Sumber: BI

Status NPF pada prinsipnya didasarkan pada ketepatan waktu bagi nasabah untuk membayarkan kewajiban, baik berupa pembagian bagi hasil maupun pengembalian pokok pinjaman. Proses pemberian dan pengelolaan kredit yang baik diharapkan dapat menekan NPF secepat mungkin. Dengan kata lain, tingginya NPF sangat dipengaruhi oleh kemampuan bank-bank syariah dalam menjalankan proses pemberian kredit dengan baik maupun dalam hal pengelolaan kredit, termasuk tindakan pemantauan (monitoring) pengembalian bila terdapat indikasi penyimpangan kredit maupun indikasi gagal bayar. Persamaannya adalah sebagai berikut :

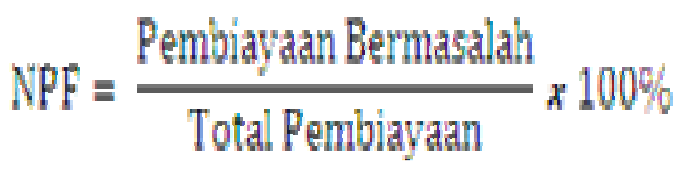


Standar terbaik NPF menurut Bank Indonesia adalah bila NPF berada dibawah $5 \%$. Variabel ini mempunyai bobot nilai 20. Skor nilai NPF ditentukan sebagai berikut:

a. Lebih dari $8 \%$, skor nilai $=0$

b. Antara $5 \%-8 \%$, skor nilai $=$ $80 \%$

c. Antara 3\% $-5 \%$, skor nilai = $90 \%$

d. Kurang dari 3\%, skor nilai = $100 \%$

Semakin besar rasio NPF, maka kualitas pembiayaan yang diberikan oleh bank syariah semakin menurun. Rasio NPF yang tinggi mengakibatkan kelancaran kegiatan usaha bank syariah menjadi terganggu, sehingga tingkat kesehatan bank pun menjadi menurun. Bank Indonesia menetapkan bahwa kualitas pembiayaan yang baik apabila jumlah pembiayaan yang bermasalah (non performing financing) maksimal sebesar 5\% dari seluruh total pembiayaan yang diberikan. Rasio NPF ini merupakan rasio penunjang dalam menganalisis komponen faktor kualitas asset. Tujuan perhitungan rasio NPF ini adalah untuk mengukur tingkat permasalahan pembiayaan yang dihadapi oleh bank.
Menurut Priatin dan Adnan (2005), semakin ketat kebijakan kredit/analisis pembiayaan yang dilakukan manajemen bank (semakin ditekan tingkat NPF) akibat rasio NPF sebelumnya tinggi, akan menyebabkan tingkat penyaluran pembiayaan menurun. Hal ini disebabkan karena bank akan melakukan proses pembiayaan dengan lebih hati-hati untuk dapat menghindari resiko pembiayaan bermasalah.

Menurut Adiwarman Karim (2006) pengendalian biaya mempunyai hubungan terhadap kinerja lembaga perbankan, sehingga semakin rendah tingkat NPF maka akan semakin besar jumlah pembiayaan yang disalurkan oleh bank dan sebaliknya semakin tinggi tingkat NPF maka jumlah pembiayaan yang akan disalurkan semakin sedikit untuk menekan NPF.

Berdasarkan pemaparan teori di atas, maka dapat disimpulkan bahwa non performing financing adalah suatu pembiayaan bermasalah dimana pembayaran angsuran pokok dan bagi hasilnya telah lewat dari sembilan puluh hari atau lebih setelah jatuh tempo dan digolongkan sebagai pembiayaan 
kurang lancar, diragukan dan macet.

\section{Bagi Hasil}

Hal yang membedakan antara lembaga keuangan non Islami dan Islam terletak pada pengembalian dan pembagian keuntungan yang diberikan oleh nasabah kepada lembaga keuangan dan atau yang diberikan oleh lembaga keuangan kepada nasabah, sehingga terdapat istilah bunga dan bagi hasil.

Sistem perekonomian Islam merupakan masalah yang berkaitan dengan pembagian hasil usaha harus ditentukan pada awal terjadinya kontrak kerja sama (akad), yang ditentukan adalah porsi masing-masing pihak, misalkan 40:60 yang berarti bahwa atas hasil usaha yang diperoleh, didistribusikan sebesar $40 \%$ bagi pemilik dana (shahibul maa) dan $60 \%$ bagi pengelola dana (mudharib).

Murinde, Naser, dan Wallace dalam Muhammad (2005: 24), mengatakan bahwa kontrak keuangan yang telah dikembangkan untuk menggantikan mekanisme bunga dalam transaksi keuangan Islam (syari'ah) adalah mekanisme bagi hasil. Mekanisme bagi hasil ini berlaku untuk produk penyertaan atau bentuk bisnis korporasi (kerjasama). Pihak-pihak yang terlibat dalam kepentingan bisnis ini harus melakukan transparasi dan kemitraan secara baik dan ideal. Sebab, semua pengeluaran dan pemasukan rutin yang berkaitan dengan bisnis penyertaan, bukan untuk kepentingan pribadi yang menjalankan proyek. Keuntungan yang dibagi hasilkan harus dibagi secara proporsional antara shahibul maal dengan mudharib. Dengan demikian, semua pengeluaran rutin yang berkaitan dengan bisnis mudharabah, dapat dimasukkan ke dalam biaya operasional. Keuntungan bersih harus dibagi antara shahibul maal dan mudharib sesuai dengan proporsi yang disepakati sebelumnya dan secara eksplisit disebutkan dalam perjanjian awal.

Ada dua metode penerimaan pendapatan bagi hasil, yaitu:

a. Cara menentukan jumlah rupiah pembayaran angsuran dan pokok pembiayaan, yaitu:

1) Bagi hasil netto adalah bagi hasil yang didasarkan pada pendapatan dari usaha atau proyek yang dikurangi dengan biaya-biaya yang timbul. Ini disebut metode 
bagi untung atau profit sharing.

2) Bagi hasil brutto adalah bagi hasil yang didasarkan pada pendapatan usaha atau proyek yang tidak dikurangi dengan biaya-biaya yang timbul. Ini disebut metode bagi hasil atau revenue sharing.

b. Cara pembayaran nasabah kepada bank yaitu:

1) Bagi hasil dibayarkan terpisah dengan angsuran pokok pinjaman, pada cara ini maka pendapatan bagi hasil yang diterima oleh bank bagi hasil merupakan pembayaran terpisah dari pembayaran angsuran pokok pembiayaan.

2) Bagi hasil dibayarkan tidak terpisah dengan angsuran pokok pinjaman, pada cara ini maka pendapatan bagi hasil yang diterima merupakan pembayaran bersamaan dengan pembayaran angsuran pokok pembiayaan. Sebelum menyetujui sebuah usulan pembiayaan yang diajukan oleh nasabah maka bank bagi hasil akan membuat proyeksi pembayaran terlebih dahulu.
Menurut Adiwarman Karim (2004: 194-197) hal-hal yang berkaitan dengan nisbah bagi hasil yaitu:

a. Persentase. Nisbah keuntungan harus didasarkan dalam bentuk persentase antara kedua belah pihak, bukan dinyatakan dalam nilai nominal rupiah tertentu. Nisbah keuntungan itu misalnya $40: 60,50: 50, \quad 60: 40$, atau 90:10..

b. Bagi Untung dan Bagi Rugi. Bila dalam akad mudharabah ini mendapatkan kerugian, pembagian kerugian itu bukan didasarkan atas nisbah, tetapi berdasarkan porsi modal masingmasing pihak. Itulah alasan mengapa nisbahnya disebut sebagai nisbah keuntungan, bukan nisbah saja, karena nisbah 50:50, atau 90:10 itu hanya diterapkan bila bisnisnya untung. Bila bisnisnya rugi, kerugiannya itu harus dibagi berdasarkan porsi masingmasing pihak, bukan berdasarkan nisbah. Dengan demikian, karena kerugian dibagi berdasarkan proporsi modal (finansial) shahibul-maal dalam kontrak ini adalah 100\%, maka kerugian (finansial) ditanggung $100 \%$ pula oleh shahibul maal. 
Di lain pihak, karena proporsi modal (finansial) mudharib dalam kontrak ini adalah $0 \%$, jika terjadi kerugian mudharib akan menanggung kerugian (finansial) sebesar $0 \%$ pula.

c. Jaminan . Pihak mudharib yang lalai atau menyalahi kontrak ini, maka shahib almaal dibolehkan meminta jaminan tertentu kepada mudharib. Jaminan ini akan disita oleh shahib al-maal jika ternyata timbul kerugian karena mudharib melakukan kesalahan, yakni lalai dan ingkar janji. Kerugian yang timbul disebabkan karena faktor resiko bisnis, jaminan mudharib tidak dapat disita oleh shahib al-maal.

d. Menentukan Besarnya Nisbah. Besarnya nisbah ditentukan berdasarkan kesepakatan masing-masing pihak yang berkontrak.

e. Cara Menyelesaikan Kerugian . Jika terjadi kerugian, cara menyelesaikannya adalah diambil terlebih dahulu dari keuntungan, karena keuntungan merupakan pelindung modal. Kemudian bila kerugian melebihi keuntungan, baru diambil dari pokok modal.

Menurut Karim, bank syariah menerapkan nisbah bagi hasil terhadap

produk-produk pembiayaan yang berbasis Natural Uncertainty Contracts (NUC), yakni akad bisnis yang tidak memberikan kepastian pendapatan, bagi dari segi jumlah maupun waktu. Penetapan nisbah bagi hasil pembiayaan ditentukan dengan mempertimbangkan referensi tingkat margin keuntungan dan perkiraan tingkat keuntungan bisnis yang dibiayai. Karim juga berpendapat bahwa, tingkat bagi hasil berpengaruh terhadap jumlah permintaan permbiayaan syariah. Bila tingkat bagi hasil kepada nasabah lebih besar daripada ratarata suku bunga perbankan nasional, maka pembiayaan syariah semakin kompetitif. Dengan demikian, semakin rendah tingkat bagi hasil yang diambil oleh bank syariah akan semakin besar pembiayaan yang diminta oleh masyarakat dan atau akan semakin besar pula pembiayaan yang dapat disalurkan oleh bank.

\section{METODOLOGI PENELITIAN}

Tujuan Penelitian

1. Untuk mengetahui seberapa besar pengaruh non performing financing terhadap pembiayaan mudharabah. 
2. Untuk mengetahui seberapa besar pengaruh bagi hasil terhadap

pembiayaan mudharabah.

3. Untuk mengetahui seberapa besar pengaruh non performing financing dan bagi hasil terhadap Pembiayaan mudharabah.

Metode penelitian yang digunakan dalam penelitian ini adalah metode ekspos fakto. Menurut Kerlinger (dalam Husein Umar, 2009: 28), penelitian ekspos fakto merupakan pencarian empirik yang sistematis di mana peneliti tidak dapat mengendalikan variabel bebasnya karena peristiwa itu telah terjadi atau sifatnya tidak dapat dimanipulasi. Cara menerapkan metode penelitian ini yaitu dengan menganalisis peristiwa-peristiwa yang terjadi dari tahun-tahun sebelumnya untuk mengetahui faktor-faktor yang dapat menimbulkan kejadian tersebut.

Metode ini bermanfaat untuk menggambarkan dan mencari hubungan antara dua variabel atau lebih serta mengukur seberapa besar atau seberapa erat hubungan antar variabel yang diteliti.

\section{HASIL PENELITIAN}

Berdasarkan hasil pengolahan data diperoleh persamaan regresi berganda sebagai berikut:
$Y=3.390,426-59,832(X 1)-$

131,688 (X2) + 0,909(Lag_y)

Keterangan:

$Y=$ Pembiayaan Mudharabah

$\mathrm{X} 1$ =NPF

X2 = Bagi Hasil

Lag_Y $=$ Pembiayaan Mudharabah periode sebelumnya

Variabel Lag_Y dimasukkan sebagai variabel independen dalam persamaan karena terdapat kelemahan dalam persamaan sebelumnya, di mana terjadi pelanggaran asumsi autokorelasi. Variabel lag dari $Y$ ini adalah selang waktu atau jeda waktu yang diperlukan variabel bebas $(Y)$ untuk mempengaruhi variabel tidak bebas (Suharyadi dan Purwanto SK, 2004:).

Persamaan di atas mempunyai artinya bahwa:

(1) Ketika NPF (X1) dan bagi hasil (X2) sama dengan 0 (nol) maka pembiayaan mudharabah yang disalurkan perbankan syariah Indonesia sebesar Rp 3390,426 (dalam miliar).

(2) Koefisien regresi variabel NPF (X1) sebesar -59,832; artinya jika NPF mengalami kenaikan $1 \%$, maka nilai pembiayaan mudharabah (Y) akan mengalami penurunan sebesar 
59,832 (miliar rupiah) dengan asumsi variabel independen lain nilainya tetap. Koefisien bernilai negatif artinya terjadi hubungan negatif antara NPF dengan pembiayaan mudharabah, semakin tinggi NPF maka semakin menurun nilai pembiayaan mudharabah. Secara teoritis ini sudah tepat, namun berdasarkan uji signifikasi koefisien regresi ini, NPF tidak mempunyai pengaruh yang berarti terhadap pembiayaan mudharabah.

Hasil penelitian ini sesuai dengan Hasil penelitian dari Pratin dan Akhyar (2005) yang berjudul "Analisis Hubungan Simpanan, Modal Sendiri, NPF, Prosentase Bagi Hasil dan Markup Keuntungan Terhadap Pembiayaan pada Perbankan Syariah (Studi Kasus Pada Bank Muamalat Indonesia)", yang menunjukkan bahwa NPF tidak mempunyai hubungan yang signifikan terhadap pembiayaan. Beberapa hal yang menyebabkan perubahan tingkat NPF tidak mempunyai pengaruh signifikan terhadap jumlah pembiayaan mudharabah, yaitu karena penanganan pembiayaan bermasalah pada bank syariah itu sendiri. Menurut Muhammad (2002), penanganan pembiayaan bermasalah khususnya pembiayaan yang diragukan atau macet oleh bank syariah lebih banyak dilakukan dengan cara rescheduling, yaitu menjadwal kembali jangka waktu angsuran serta memperkecil jumlah angsuran, reconditioning, yaitu memperkecil bagi hasil usaha dan pengalihan atau pembiayaan ulang dalam bentuk pembiayaan al-qardhul hasan, yaitu mengangsur pengembalian pokok saja tanpa tambahan bagi hasil daripada mengeksekusi jaminan. Eksekusi jaminan dilakukan sebagai jalan terakhir bila cara lain yang lebih manusiawi tidak berhasil mengatasi pembiayaan bermasalah. Selain itu longgarnya kebijakan pembiayaan bank syariah inilah yang membuat rasio NPF kurang mempengaruhi pembiayaan mudharabah yang disalurkan oleh perbankan syariah.

(3) Koefisien regresi variabel bagi hasil (X2) sebesar -131,688; artinya jika bagi hasil yang diperoleh perbankan syariah Indonesia mengalami kenaikan $1 \%$, maka nilai pembiayaan 
mudharabah yang dapat disalurkan (Y) akan mengalami perurunan sebesar 131,688 (miliar rupiah) dengan asumsi variabel independen lain nilainya tetap. Koefisien bernilai negatif artinya terjadi hubungan negatif antara bagi hasil dengan pembiayaan mudharabah, semakin tinggi bagian bagi hasil yang ditetapkan perbankan syariah Indonesia untuk bank syariah

maka semakin sedikit pembiayaan mudharabah yang diminta oleh masyarakat. Secara teoritis sudah tepat, di mana jika nisbah bagi hasil yang diterima bank syariah rendah, berarti bagi hasil yang diterima mayarakat akan lebih tinggi. Dan berdasarkan uji signifikasi koefisien regresi, maka kedua variabel mempunyai pengaruh yang signifikan.

(4) Lag_Y (nilai koefisien $\mathrm{Y}_{\mathrm{t}-1}$ ), peneliti meyakini bahwa pembiayaan mudharabah yang disalurkan oleh perbankan syariah Indonesia pada bulan t-1 memiliki pengaruh yang signifikan terhadap variabel pembiayaan mudharabah pada bulan $\mathrm{t}$ sebesar Rp 0,909 miliar atau Rp 909.000.000. Jadi setiap ada kenaikan pembiayaan mudharabah sebesar Rp 1.000.000.000,-pada bulan lalu, maka akan meningkatkan pembiayaan mudharabah bulan ini sebesar Rp 0,909 miliar. Hal ini didasarkan pada faktor psikologis perbankan syariah dimana ketika ingin meningkatkan pembiayaan mudharabah pada bulan sekarang maka masih mempertimbangkan penyaluran pembiayaan bulan sebelumnya. Dan berdasarkan uji signifikasi koefisien regresi, maka kedua variabel mempunyai pengaruh yang berarti.

(5) Walaupun secara parsial NPF tidak mempunyai pengaruh yang berarti pada pembiayaan mudharabah, namun berdasarkan uji $F$, ketiga variabel bebas mempunyai pengaruh yang berarti pada pembiayaan mudharabah.

Hasil perhitungan dan uji koefisien korelasi secara parsial dan simultan:

(1) Hubungan antara Pembiayaan Mudharabah dan NPF menunjukkan nilai korelasi negative yang rendah $(-0,226)$, hal ini berarti bahwa jika NPF tinggi maka pembiayaan 
mudharabah akan menurun dan sebaliknya. Akan tetapi berdasarkan uji koefisien korelasi parsial ini, kedua variabel tidak mempunyai korelasi yang berarti.

(2) Hubungan antara Pembiayaan Mudharabah dan Bagi Hasil menunjukkan nilai korelasi negative yang rendah $(-0,390)$, hal ini berarti bahwa jika nisbah bagi hasil yang ditetapkan perbankan syariah Indonesia tinggi, maka pembiayaan mudharabah akan menurun, dan sebaliknya. Dan berdasarkan uji koefisien korelasi parsial ini, kedua variabel mempunyai korelasi yang berarti.

(3) Hasil perhitungan koefisien korelasi (R) dan Uji korelasi simultan menunjukkan adanya korelasi yang positif dan sangat kuat antara variabel NPF dan Bagi Hasil terhadap variabel Pembiayaan Mudharabah $(0,996)$

Hasil perhitungan Koefisien Determinasi $\left(R^{2}\right)$ digunakan untuk mengetahui seberapa besar variasi variabel dependen dapat dijelaskan oleh variabel independennya menunjukkan nilai sebesar 0,991, artinya bahwa ketiga variabel bebas dalam model persamaan mampu menjelaskan $99.1 \%$ dari variasi nilai variabel pembiayaan mudharabah, sedangkan sisanya $0.9 \%$ dijelaskan oleh variabel-variabel lain yang tidak ada di dalam model. Sehingga dapat dikatakan bahwa model yang digunakan sudah tepat untuk menjelaskan hubungan antara variabel NPF, Bagi HAsil dan Lag_Y $_{\mathrm{t}-1}$ terhadap pembiayaan mudharabah.

Uji gejala klasik hanya menunjukkan adanya autokorelasi antara variabel independennya. Hal tersebut sudah dapat diatasi dengan menmbahkan satu variabel lagi (Lag_Y)

\section{PENUTUP}

Besarnya pembiayaan mudharabah periode sekarang yang disalurkan perbankan syariah dalam penelitian ini hanya dipengaruhi oleh nisbah bagi hasil yang diterima bank periode sebelumnya dan besarnya penyaluran pembiayaan mudharabah periode sebelumnya, sedangkan non performing financial (NPF) periode sebelumnya tidak mempunyai pengaruhi yang berarti pada pembiayaan mudharabah peride sekarang.

Tidak adanya pengaruh yang signifikan dari variabel NPF terhadap Pembiayaan

Mudharabah 
diindikasikan karena kemudahan memperoleh pembiayaan mudharabah, dan juga dalam penanganan NPF menggunakan skema reschedulling dan reconditioning serta al qordhul hasan.

Di sisi lain, pembiayaan mudharabah masih dipengaruhi oleh nisbah bagi hasil yang diterima bank dan besarnya pembiayaan mudharabah periode sebelumnya.

\section{Saran}

Pembiayaan mudharabah yang berpihak pada ummat dan para nasabahnya dengan kebijakan rescheduling, reconditioning dan merubah pembiayaan mudharabah menjadi al qordhul hasan sudah tepat. Namun jika pembiayaan mudharabah sudah diubah menjadi al qordhul hasan atau sudah direschedulling, maka sebaiknya nilainya tidak diperhitungkan lagi dalam kelompok NPF, karena dari hasil perhitungan seolah-olah bank syariah dalam mengelola pembiayaan mudharabah membahayakan kesehatan bank, dimana seharusnya besarnya NPF akan mempengaruhi besarnya pembiayaan mudharabah.

\section{DAFTAR PUSTAKA}

Adiwarman Karim, Bank Islam: Analisis Fikih dan Keuangan, Jakarta: Raja Grafindo, 2006. Lukman Dendawijaya, Manajemen Perkreditan, Jakarta: Ghalia Indonesia, 2001

Muhammad, Manajemen Bank Syariah, Yogyakarta: (UPP) AMPYKPN, 2002.

Muhammad, Manajemen Dana Bank Syariah, Yogyakarta:

Ekonisia, 2004.

Nadratuzzaman, Hasan Ali, dkk. Materi Dakwah Ekonomi

Syariah,Jakarta: PKES, 2008.

Priatin, Akhyar Adnan. Analisis

Hubungan Simpanan, Modal

Sendiri, NPL, Prosentase Bagi Hasil dan Mark up Keuntungan Terhadap

Pembiayaan Pada Perbankan Syariah Studi Kasus Bank Muamalat Indonesia (BMI).

Edisi Khusus on Finance, Sinergi, Program magister manajemen Universitas Islam Indonesia, 2005.

Retnadi, Djoko dkk. Obligasi Rekapitalisasi Perbankan: Geneologi, Masalah dan Solusi, Cetakan Pertama, Masyarakat Profesional Madani, Jakarta, 2005 
Siswanto Sutojo. Manajemen Terapan Bank. Jakarta:

Pustaka Binaman Pressindo, 2008.

Slamet Wiyono, "Cara Mudah Memahami Akuntansi

Perbankan Syariah

Berdasarkan PSAK dan PAPSI", Jakarta: Gramedia Widiasarana Indonesia, 2005.

Suhardjono, Manajemen

Perkreditan, Jakarta: UPPAMPYKPN, 2003.

Syafi'i Antonio. Bank Syari'ah Dari

Teori Ke Praktek, cetakan pertama, GIP, Jakarta, 2001.

Syafi'i Antonio. Dasar-dasar Manajemen Bank Syariah. Jakarta: Pustaka Alvabet, 2002

http://informasi-

bogor.com/tinjauan-islamterhadap-pembiayaan-bagihasil-dan-implementasinya/ (Diakses pada tanggal $10 \mathrm{Mei}$ 2012)

Muhammad,"Penyesuaian masalah agensi dalam kontrak pembiayaan mudharabah",
Jurnal Ekonomi Syariah (Muamalah), vol. 3 No. 1, Januari 2005, p. 24

Yayat Sujatna,"Analisis faktor internal dan Eksternal yang Mempengaruhi Jumlah Pembiayaan Bagi Hasil pada Bank Syari'ah", Jurnal Ekonomi \& Kemasyarakatan, vol. 7 No. 3, Mei-Agustus 2010, p. 452-453

Wiroso, Penghimpunan Dana Dan Distribusi Hasil Usaha bank Syariah. Jakarta: PT Gramedia Widasarana Indonesia, 2005.

Adiwarman karim, Bank Islam (analisis fiqih dan keuangan), Jakarta: PT Raja Grafindo Persada, 2004, p.194-197

Husein Umar. Metode Penelitian untuk Skripsi dan Tesis Bisnis Edisi 2, (PT Raja Grafindo Persada: Jakarta, 2009). p.28 Suharyadi dan Purwanto SK, Statistika Untuk Ekonomi dan Keuangan Modern, (Jakarta: Salemba Empat, 2004), hlm. 558. 